\title{
Cholesterol Metabolism
}

\section{CHOLESTEROL ABSORPTION AND EXCRETION IN MAN*}

\author{
By R. P. COOK, D. C. EDWARDS AND CHRISTINE RIDDELL \\ Department of Biochemistry, Queen's College, Dundee, University of St Andrews
}

(Received 16 May 1955)

The experiments to be described were designed primarily to determine the extent of absorption in man of crystalline cholesterol and of cholesterol taken in the form of eggs. The constituents of the ether-ethanol extracts of the faeces before and after the ingestion of the cholesterol were examined to determine the nature of the excretory products.

A preliminary account of the findings has been given by Cook \& Edwards (1951), Edwards \& Cook (1951) and Cook, Edwards \& Riddell (1952).

\section{DIET AND METHODS}

Diet. Two separate experiments on the same male subject (age 45 years, wt. $71 \mathrm{~kg}$.) were carried out, a period of 10 months elapsing between each experiment. Apart from the special egg diet which contained twenty eggs, no alterations were made in dietary habit. The subject's health and appetite were uniformly good and his weight was constant.

The first experiment consisted in the collection of faeces for 5 days on a normal diet and on the 3 days following the ingestion of $10 \mathrm{~g}$. of cholesterol (Glaxo Recrystallized) suspended in $50 \mathrm{~g}$. of olive oil. The cholesterol was taken in two lots of $5 \mathrm{~g}$. in oil, one at 1.30 p.m. and the other at 6 p.m. In the second experiment twenty eggs made into various dishes were consumed over à period of $15 \mathrm{hr}$. Faeces from the normal diet were collected 2 days before the ingestion of the egg diet and for the 4 days following. No urine was collected, as loss of sterol by this route is negligible (see Cook, 1952).

Collection and treatment of faeces. During the normal period and after ingestion of crystalline cholesterol bowel habit was regular, but about $3 \mathrm{hr}$. after the first meal on the egg diet there was a transient loosening, the material collected being designated 'transition'. Thereafter regular habits were maintained.

The faeces were collected daily, normally after breakfast, into a tared cellophan bag and weighed. The bag and its contents were then dried in vacuo in a steam-jacketed vessel to constant weight and extracted in a continuous extractor with ether until no colour was visible in the extract. The material was then removed from the extractor, powdered in a mortar and the extraction was completed with ethanol. The solvents were removed and the extracts were weighed. In the first experiment the ether-soluble and the ethanolsoluble extracts were weighed and analysed separately, but in the second experiment the two extracts were combined. The reported results are for the combined extracts.

* Part 6: Cook, Edwards, Riddell \& Thomson (1955). 15
Analysis and treatment of extracts. Samples were analysed for free, total and saturated sterols by the methods previously described (Riddell \& Cook, 1955). The procedures used for saponification, removal of unsaponifiable matter (UM), and recovery of steam-volatile and etherextractable acids and for the fractionation of these were the same as those described by Riddell \& Cook (1955) and Edwards \& Cook (1955).

Eggs. Four eggs were dried with $\mathrm{Na}_{2} \mathrm{SO}_{4}$ on a water bath. The mixture was powdered and extracted and the lipid was fractionated as for the faeces.

Blood. This was collected in oxalated tubes and the plasma separated. Total ether-soluble lipid, free and total sterol were determined on certain samples.

Chromatography. Adsorption chromatography on alumina was used for fractionating the unsaponifiable matter and the methyl esters of the acids by the methods described previously (Riddell \& Cook, 1955; Edwards \& Cook, 1955).

\section{RESULTS}

The average composition of the normal diet and the composition of the egg diet are given in Table 1, the food values being calculated from the tables of

Table 1. The main constituents of the diets used

The values given are g./day

$\begin{array}{lcc} & \text { Average } & \\ & \text { normal diet } & \text { Egg diet } \\ \text { Carbohydrate } & 303 & 412 \\ \text { Fat } & 134 & 357 \\ \text { Protein } & 85 & 175 \\ \text { Cholesterol } & 0.58 & 6 \cdot 9 \\ \text { Phytosterols } & 0.08 & 0 \cdot 15 \\ \text { Total calories per day } & 3140 & 6120\end{array}$

McCance \& Widdowson (1946). The values for cholesterol in ordinary foods were taken from those determined by Okey (1945) and the values for plant sterols from those collected by Lange (1950). The crystalline cholesterol preparation contained $98 \%$ of cholesterol (Riddell \& Cook, 1955). The following values per egg were found: total extract $7 \cdot 1$ g., UM $412 \mathrm{mg}$., total sterol $343 \mathrm{mg}$. Twenty eggs therefore contain $8.25 \mathrm{~g}$. of UM and $6.9 \mathrm{~g}$. of sterol. The total digitonin-precipitable sterol contained $4 \%$ of 'fast acting' sterols, mainly lathosterol (Fieser, 1951). The diet contained about 


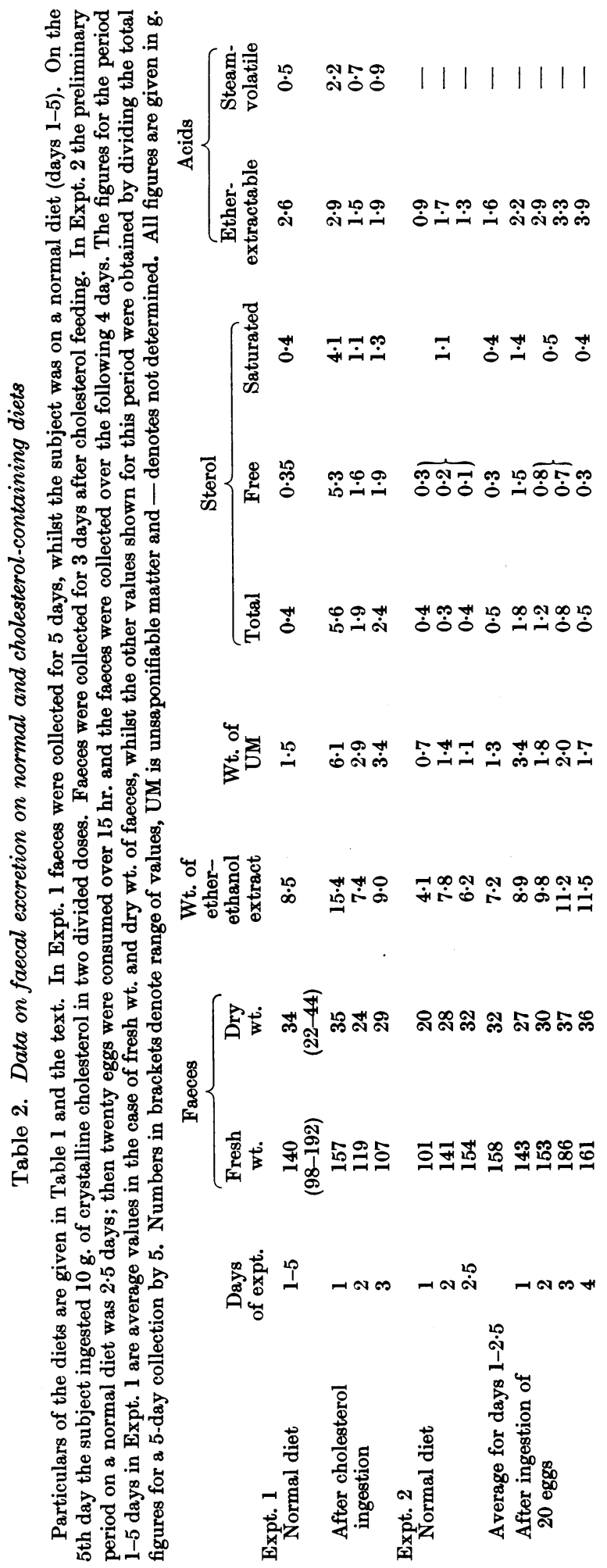

$10 \mathrm{~g}$. of unavailable carbohydrate (fibre) per day and the consumption of alcohol yielded about $10 \%$ of the total calories.

The values in Table 2 for the normal excretion have been calculated on an average daily basis by dividing the totals in the normal period of the first experiment by 5 ; in the normal period of the second experiment the transition excretion has been counted as a half day and the total values have been divided by $2 \cdot 5$. On such a daily basis the values for weight of faeces, extract, UM and sterol excreted for the two periods are very similar. The amount of ether-extractable acids is less in the normal period of the second experiment.

On the first day after ingestion of crystalline cholesterol there was a marked increase in the amount of extract, UM and total sterol. The excretion of UM and of sterol continued for the next 2 days. There was an increase in the excretion of ether-extractable acids on the first day after ingestion but the value thereafter fell to lower than normal. There was a marked rise in the amount of steam-volatile acids on the first day, but thereafter the amount decreased.

On the egg diet the amount of extract increased for the 4 days after ingestion. The excretion of UM was increased as was that of the total sterol. There was a marked increase in the excretion of etherextractable acids. Further consideration of the excreted material is given later.

\section{Absorption of cholesterol}

From the values given in Table 2 the apparent absorption of cholesterol may be calculated. In Table 3 are given the values for the absorption of unsaponifiable matter and of sterol. The small additional amounts of UM and of sterol ordinarily ingested are not shown. Calculated on the basis of UM the absorption for crystalline cholesterol is $21 \%$ and for egg $55 \%$. On a sterol basis the absorptions are 11 and $67 \%$ respectively. There is thus a marked difference in absorption. The general conclusion may be drawn that, in one subject, of $10 \mathrm{~g}$. of crystalline cholesterol ingested, about $15 \%$ was absorbed over 3 days (or about $8 \mathrm{mg}$. $/ \mathrm{kg}$. body wt./day), and of $6.9 \mathrm{~g}$. of egg cholesterol ingested about $60 \%$ was absorbed over 4 days (or about $15 \mathrm{mg} . / \mathrm{kg}$. body wt./day).

Level of sterol in plasma. The values for free and total cholesterol were determined before and $18 \mathrm{hr}$. after the ingestion of crystalline cholesterol but there was no demonstrable increase. With the egg diet the sample of plasma obtained $6 \mathrm{hr}$. after the beginning of the diet, when about $4 \mathrm{~g}$. of cholesterol and $210 \mathrm{~g}$. of fat had been consumed, showed a significant rise in total lipid and in total cholesterol and the percentage of ester had risen above the 
Table 3. Calculated values for sterol absorption after ingestion of crystalline cholesterol (Expt. 1) and after ingestion of twenty eggs (Expt. 2)

Experimental details and data on which the calculations are based are given in Table 2. UM denotes unsaponifiable matter. All values other than those in the last horizontal row are in $\mathrm{g}$.

\begin{tabular}{|c|c|c|c|c|}
\hline & \multicolumn{2}{|c|}{ Expt. 1} & \multicolumn{2}{|c|}{ Expt. 2} \\
\hline & UM & Sterol & UM & Sterol \\
\hline $\begin{array}{l}\text { Amount eaten additional to that } \\
\text { present in normal diet }(A)\end{array}$ & $10 \cdot 0$ & $9 \cdot 8$ & $8 \cdot 3$ & $6 \cdot 9$ \\
\hline $\begin{array}{l}\text { Total amount excreted after } \\
\text { cholesterol feeding* }(B)\end{array}$ & $12 \cdot 4$ & $\mathbf{9 \cdot 9}$ & 8.9 & $4 \cdot 3$ \\
\hline $\begin{array}{l}\text { Normal excretion* } *^{\circ}(C) \\
\text { Excess excreted }(B-C)\end{array}$ & $\begin{array}{l}4 \cdot 5 \\
7.9\end{array}$ & $\begin{array}{l}1.2 \\
8.7\end{array}$ & $\begin{array}{l}5 \cdot 2 \\
3 \cdot 7\end{array}$ & $\begin{array}{l}2 \cdot 0 \\
2 \cdot 3\end{array}$ \\
\hline Amount absorbed $(A-B+C)$ & $2 \cdot 1$ & $1 \cdot 1$ & $4 \cdot 6$ & $4 \cdot 6$ \\
\hline Amount absorbed (\%) & 21 & 11 & 55 & 67 \\
\hline
\end{tabular}

* This was over a period of 3 days in Expt. 1 and of 4 days in Expt. 2.

Table 4. Contents of lipid and of total and free cholesterol in plasma before and at various times after beginning of the egg diet

For details of diet see Table 1 and text.

\begin{tabular}{lrrr} 
& \multicolumn{2}{c}{$\overbrace{\text { Total }}^{\text {Lipid }}$} & Free \\
(mg./100 ml.) & \\
Before ingestion of eggs & $\overbrace{750}$ & 230 & 100 \\
After 6 hr. & 1200 & 325 & 90 \\
After 24 hr. & 950 & 230 & 90 \\
After 4 days & 850 & 215 & 85
\end{tabular}

normal value. After $24 \mathrm{hr}$. the values had returned to normal and were still normal when tested on the fourth day (see Table 4).

\section{Unsaponifiable matter (UM)}

The nature of the UM was investigated by two methods. In the first investigation the UM from the normal diet preceding $(N)$ and the UM from day $1(C 1)$, days 2 and 3 combined $(C 2-3)$ and day $4(C 4)$ following the ingestion of egg cholesterol were studied. The separate samples were initially partitioned between aqueous methanol and light petroleum (Haslewood, 1941); the fractions were then recovered and the light-petroleum-soluble moieties were chromatographed on alumina, to yield five primary fractions of comparable nature. In essentials the method was the same as method I of Riddell \& Cook (1955).

The second investigation was devised to study the chemical nature of the total UM, and a pool was made of the remaining material from the normal and crystalline cholesterol diet experiment and material from the egg-diet experiment from which the greater part of the coprostanol and cholesterol had been removed.

\section{Method 1}

The yields (as g. and as percentage of total UM), appearances, $[\alpha]_{D}$, iodine values, and sterol estimations by quantitative Liebermann-Burchard reaction (LB) and by gravimetric digitonin precipitation $(G)$ are given in Table 5. The eluents used to obtain the various fractions are also given.

Aqueous-methanol-soluble. This fraction increased slightly after the ingestion of eggs, reaching $10 \%$ of the total UM on the fourth day. The fraction contains the most polar compounds and was shown by paper partition chromatography (see Riddell \& Cook, 1955) to contain diols and triols. A more detailed account of the composition is given below.

Fraction 1. This increased slightly in amount after the ingestion of eggs, but the materials were similar in appearance and properties. They were white crystalline waxes (m.p. 38-42 ${ }^{\circ}$ ) with no optical activity. The LB test was 'fast' but gave a low sterol value, and no material was precipitable with digitonin. This fraction is considered to consist mainly of saturated and unsaturated hydrocarbons (see below).

Fraction 2. The fractions from $C 1$ and $C 2-3$ were increased above that of $N$. The acetyl value for the $N$ fraction was 150 and for the combined $C$ fractions it was 100 . The gummy fractions could not be crystallized either before or after acetylation. The fraction is considered to consist mainly of higher alcohols with an admixture of sterols.

Fraction 3. This increased slightly after the ingestion of eggs, the effect being most marked in sample $C 4$. The value for digitonin-precipitable sterol was greater than that obtained by the LB test. The $N$ and $C$ fractions all gave a strongly positive Zimmermann test, indicating the presence of 3-ketosteroids. Spectrophotometric examination indicated the presence of cholest-4-en-3-one in the $C$ fractions. 
The $N$ and all the $C$ fractions were combined $(0.18$ g.), treated with Girard $T$ reagent and the ketonic fraction $(0.11$ g.) was recovered. Polarographic investigation by the method of Robertson (1955) showed the presence of cholestanone (7.5 mg.) and coprostanone (4 mg.). Chromatography of the 2:4-dinitrophenylhydrazones showed that other constituents were also present.

Fraction 5. The amount of this fraction increased somewhat in $C 1$ and was markedly increased in $C 2-3$; in $C 4$ there was a decrease. The fractions from $N, C 1$ and $C 1$ and $C 2-3$ are considered to consist mainly of unsaturated sterols.

Components of fractions 4 and 5 . The remainders of the fractions of similar nature were combined to form the following pools: fraction $4 N$ (1.50 g.); fraction $4 C(2.84 \mathrm{~g}$.) from $C 1, C 2-3$ and $C 4$; fraction $5 N(0.77 \mathrm{~g}$.$) ; and fraction 5 C(3.57 \mathrm{~g}$.) from $C 1, C 2-3$ and $C 4$. These fractions were chromatographed separately on alumina by the method shown in Fig. 1 and a number of subfractions obtained. The yields and properties of these are given in Table 6.

Fraction 4.1 from both $N$ and $C$ material was a yellow, low-melting-point, dextrorotatory wax with a low iodine value. No digitonin-precipitable sterol was present and a slight $L B$ reaction was obtained. It is suggested that the fraction contains $3 \alpha$-stanols. The amount of this fraction is increased after sterol feeding.

Table 5. Yields and properties of various fractions of unsaponifiable matter (UM) of lipids obtained from faeces at various periods of the experiments

The lipid extracts were obtained from faeces while the subject was on a normal diet $(N)$ and 1 day $(C 1), 2-3$ days $(C 2-3)$ and 4 days $(C 4)$ after the ingestion of eggs. The fractions were obtained by chromatography on alumina (Riddell \& Cook, 1955). The values for the quantitative Liebermann-Burchard test (LB) and those for the gravimetric digitonin estimation (G) are expressed as percentage of the fraction examined. The proportions of the solvents in eluent mixtures are given as $\%(v / v)$. The light petroleum (LP) had b.p. $40-60^{\circ}$.

Fraction and eluents used

Aqueous-methanol-soluble

(1) LP 100 and LP 80-benzene 20

(2) LP 20-benzene 80 and benzene 100

(3) Benzene 80-ether 20 and benzene 20 -ether 80

(4) Ether 100

(5) Ether 80-ethanol 20 and graded mixtures up to ethanol 100

\begin{tabular}{|c|c|c|c|c|}
\hline & $N$ & $C 1$ & $C 2-3$ & $C 4$ \\
\hline $\begin{array}{l}\text { Wt. (g.) } \\
\% \text { of UM }\end{array}$ & $\begin{array}{l}0 \cdot 18 \\
5 \cdot 6\end{array}$ & $\begin{array}{l}0.20 \\
5.9\end{array}$ & $\begin{array}{l}0 \cdot 14 \\
3 \cdot 8\end{array}$ & $\begin{array}{c}0 \cdot 17 \\
10 \cdot 0\end{array}$ \\
\hline $\begin{array}{l}\text { Appearance } \\
{[\alpha]_{D}}\end{array}$ & $+2^{\circ}$ & $+8^{\circ}$ & $+10^{\circ}$ & $-8^{\circ}$ \\
\hline $\begin{array}{l}\text { Wt. (g.) } \\
\% \text { of UM } \\
\text { Appearance }\end{array}$ & $\begin{array}{l}0 \cdot 11 \\
3 \cdot 4\end{array}$ & $\begin{array}{r}\quad 0.09 \\
2.8 \\
\text { White c }\end{array}$ & $\begin{array}{c}0.06 \\
1.6 \\
\text { e waxes }\end{array}$ & $\begin{array}{l}0.04 \\
2 \cdot 3\end{array}$ \\
\hline & $\mathbf{0}$ & 0 & 0 & 0 \\
\hline Iodine value & 24 & 101 & 20 & 25 \\
\hline Sterol $\int$ LB & 5 & 10 & 2 & 15 \\
\hline Sterol $\{\mathrm{G}$ & $\mathbf{0}$ & 0 & $\mathbf{0}$ & 0 \\
\hline $\begin{array}{l}\text { Wt. (g.) } \\
\text { \% of UM } \\
\text { Appearance }\end{array}$ & $\begin{array}{l}0.03 \\
0.9\end{array}$ & $\begin{array}{l}0 \cdot 09 \\
2 \cdot 8 \\
\text { Gold }\end{array}$ & $\begin{array}{c}0.01 \\
1.6 \\
\text { gums }\end{array}$ & $\begin{array}{l}0 \cdot 11 \\
2 \cdot 3\end{array}$ \\
\hline$[\alpha]_{\mathrm{p}}$ & $\mathbf{0}$ & $+30^{\circ}$ & 0 & $+9^{\circ}$ \\
\hline Iodine value & 97 & 73 & 85 & 58 \\
\hline Sterel $\int \mathrm{LB}$ & 10 & 2 & 10 & 2 \\
\hline Sterol $\{G$ & 25 & 10 & 30 & 10 \\
\hline Wt. (g.) & 0.07 & 0.08 & 0.06 & $0 \cdot 18$ \\
\hline$\%$ of UM & $2 \cdot 2$ & $2 \cdot 4$ & $1 \cdot 6$ & $10 \cdot 6$ \\
\hline Appearance & \multicolumn{4}{|c|}{ Yellow-brown gums } \\
\hline & $+30^{\circ}$ & $+25^{\circ}$ & $+30^{\circ}$ & $-9^{\circ}$ \\
\hline Iodine value & 40 & 43 & 36 & 56 \\
\hline Sterol LB & 20 & 60 & 5 & 40 \\
\hline sterol $\{\mathrm{G}$ & 100 & 80 & 10 & 80 \\
\hline $\begin{array}{l}\text { Wt. (g.) } \\
\% \text { of UM }\end{array}$ & $\begin{array}{c}1 \cdot 71 \\
53 \cdot 2\end{array}$ & $\begin{array}{c}1 \cdot 70 \\
50 \cdot 0\end{array}$ & $\begin{array}{c}0 \cdot 68 \\
18 \cdot 4\end{array}$ & $\begin{array}{c}0.96 \\
56.5\end{array}$ \\
\hline Appearance & \multicolumn{4}{|c|}{ Yellow crystalline solids } \\
\hline$[\alpha]_{\mathrm{D}}$ & $+20^{\circ}$ & $+21^{\circ}$ & $+20^{\circ}$ & $+16^{\circ}$ \\
\hline Iodine value & 23 & 11 & 14 & 10 \\
\hline Sterol $\{\mathrm{LB}$ & 30 & 30 & 20 & 45 \\
\hline Sterol $\{\mathrm{G}$ & 80 & 80 & 90 & 90 \\
\hline & $0 \cdot 88$ & $1 \cdot 07$ & $2 \cdot 67$ & $0 \cdot 14$ \\
\hline $\begin{array}{l}\text { \% of UM } \\
\text { Appearance }\end{array}$ & \multicolumn{3}{|c|}{ Brown gums } & $8 \cdot 2$ \\
\hline$[\alpha]_{\mathrm{D}}$ & $-20^{\circ}$ & $-25^{\circ}$ & $-30^{\circ}$ & $+24^{\circ}$ \\
\hline Iodine value & & 59 & 61 & 154 \\
\hline Sterol $\{\mathrm{LB}$ & 50 & 70 & 70 & 70 \\
\hline Sterol \} G & 80 & 90 & 50 & 90 \\
\hline
\end{tabular}


Fractions 4.2 from $N$ and $C$ were white crystalline solids of similar melting points and optical rotations. The iodine value of the $C$ material was higher than that of the $N$ fraction. All the sterol was precipitable with digitonin. The LB test gave a lower value for total sterol. The main component appears to be coprostanol with an admixture of cholesterol (or other $\Delta^{5}$-stenol) and cholestanol. The fraction is increased after sterol feeding.

\section{Method 2}

The remainder of the UM excreted (16.8 g.) before and during the 3 days after the ingestion of crystalline cholesterol and the residual fractions (3.1 g.) from the egg-diet experiment, from which the greater part of the cholesterol and coprostanol had been removed, were combined. The total corresponds to about 10 days' collection.

Fraction 5

\begin{tabular}{|c|c|c|}
\hline \multicolumn{3}{|c|}{ Chromatography } \\
\hline Eluates from LP 100 & Ether 95-ethanol 5 & Ethanol 100 \\
\hline Ether 100 & Fraction 5.2 & Fraction 5.3 \\
\hline & Fraction 4 & \\
\hline & Chromatography & \\
\hline $\begin{array}{l}\text { Eluates from LP } 100 \\
\text { Benzene } 100 \\
\text { Combined to give fraction } 4.1\end{array}$ & $\begin{array}{l}\text { Benzene } 50 \text {-ether } 50 \\
\text { and ether } 100 \\
\text { Combined to give fraction } 4.2\end{array}$ & $\begin{array}{l}\text { Ether } 90 \text {-ethanol } 10 \\
\text { and ethanol } 100 \\
\text { Combined to give fraction } 4.3\end{array}$ \\
\hline
\end{tabular}

Fig. 1. Separation by chromatography on alumina of the components of fractions 4 and 5 obtained by the chromatography of the unsaponifiable matter from the egg-diet experiment (Table 5). The fractions from $C 1, C 2-3$ and $C 4$ were combined. The proportions of solvents in mixtures are given as percentages $(\mathbf{v} / \mathbf{v})$. Light petroleum (LP) had b.p. $40-60^{\circ}$.

Table 6. Yields and properties of fractions obtained from re-chromatography of $C$ fractions 4 and 5 from the egg-diet experiment and of $N$ fractions from normal diet

For details see text. Sl. =slight positive reaction.

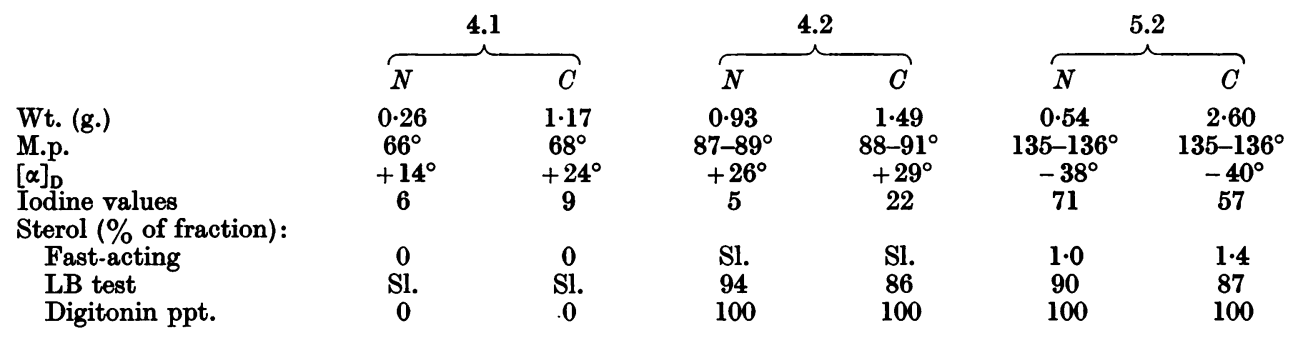

Fraction 5.2 was markedly increased after sterol feeding. The white crystalline solids consist mainly of unsaturated sterols. The properties of the $C$ fraction suggest that it was mainly cholesterol mixed with about $10 \%$ of cholestanol. The $N$ fraction had properties somewhat different from cholesterol and it probably contained phytosterols.

Fraction 5.3 ( $N 24 \mathrm{mg} ., C 95 \mathrm{mg}$.) and fraction 4.3 (N $39 \mathrm{mg}$., $C 135 \mathrm{mg}$.) were gums which gave tests for the presence of diols and triols (Riddell \& Cook, 1955). These fractions were not further investigated.
The fractionation procedure was modelled on that of method II of Riddell \& Cook (1955), in which the greater part of the cholesterol is removed by crystallization from methanol and the cholesterol-poor unsaponifiable matter (CPUM) fractionated by chromatographic and by chemical methods. The crude cholesterol was crystallized from acetic acid and the materials from the mother liquor were added to the CPUM. There was a working loss of $15 \%$, which may be regarded as having been divided among the various fractions. The results reported are of a preliminary nature and special methods are being developed to separate 
the components of the complex fractions. The following fractions were obtained:

Unaltered cholesterol (4.03 g.). This had m.p. $143^{\circ}$ and $[\alpha]_{D}-39^{\circ}$. Paper-partition chromatography showed one spot only.

Coprostanol (5.18 g.). This had m.p. 100-101 ${ }^{\circ}$ and $[\alpha]_{\mathrm{D}}+26^{\circ}$. Gravimetric and colorimetric estimations indicated that $99 \%$ of this fraction was in fact coprostanol. Paper-partition chromatography showed one spot.

Hydrocarbon fraction $(0 \cdot 13$ g.). This was a white crystalline wax, m.p. $38-42^{\circ}$, which showed a bluish fluorescence in ultraviolet light. It had no optical activity. An immediate blue LB test was obtained, but the fraction was not precipitable with digitonin. Analysis of a sample gave: C, 84.7; $\mathrm{H}, 13.6 \%$.

Fraction $2(0.88$ g.). This was obtained from the later light-petroleum and the early benzene eluents. The material was a yellow wax which formed an adduct with urea. It had no optical activity and gave an acetyl value of 49 . It is suggested that the fraction is a mixture of aliphatic alcohols and other compounds. Cetyl alcohol has been isolated from human faecal UM by Gardner (1921) and by Schoenheimer \& Hilgetag (1934), but their yields appear to be small. The nature of the other compounds is unknown but they may be oxidized hydrocarbons of the squalene type and vitamin E-like compounds which are poorly absorbed (Klatskin \& Molander, 1952).

Ketones. A yield of $0.56 \mathrm{~g}$. was obtained for the material from the Girard separation, but the yields of cholestanone (16 mg.) and coprostanone (9 mg.) show that a large proportion is unaccounted for. Chromatography of the 2:4-dinitrophenylhydrazones showed that at least five components were present (Robertson, 1955).

Stanols $(0.45 \mathrm{~g}$.). This fraction was obtained from the later light petroleum and benzene eluents. It was dextrorotatory, and an analysis gave $20 \%$ of digitonin-precipitable sterol, whereas the LB test gave $7 \%$ of sterol. A yellow colour with a green fluorescence was obtained with concentrated sulphuric acid. It is probable that this fraction contains $3 \alpha$-stanols in addition to the digitoninprecipitable sterols.

Mixed sterols. A large fraction (4.22 g.) was obtained from the benzene 50-ether 50 eluents. Fast-acting sterols (about $2 \%$ ) were present, and digitonin precipitation showed that the fraction consisted mainly of $3 \beta$-sterols. Paper-partition chromatography (Riddell \& Cook, 1955) indicated a mixture of $\Delta^{5}$-stenols and of stanols. The fraction contains residual cholesterol and coprostanol, but there is evidence for the presence of other sterols such as phytosterols. (The diet contained a total of about $1 \mathrm{~g}$. of phytosterols during the experimental period.) Windaus \& Uibrig (1915) found cholestanol in human faecal UM but gave no yields. Our attempts to isolate this compound were unsuccessful.

Final fraction (1.02 g.). This was obtained from the ether-ethanol eluents, and from the extruded column by boiling with ethanol. The fraction corresponds with the aqueous-methanol-soluble material obtained from the egg-diet experiment. The material was a dark gum with a slight dextrorotation. It contained $2 \cdot 2 \%$ of nitrogen and gave a marked Lifschütz reaction. Paper-partition chromatography (Riddell \& Cook, 1955) showed the presence of cholest-5-ene-3 $\beta: 7 \alpha$-diol, cholest-5ene-3 $\beta$ :7 $\beta$-diol, cholest-5-ene-3 $\beta$ :24- and/or :25-diol, and cholestane-3 $\beta: 5 \alpha: 6 \beta$-triol. There was a brownblack spot at the origin after spraying with $\mathrm{SbCl}_{5}$ in $\mathrm{CHCl}_{3}$. The composition of this fraction appears to be similar to the corresponding fraction obtained from rat-faecal UM (Riddell \& Cook, 1955).

\section{Acidic component}

Acids form a large percentage of the total faecal extracts and the following investigations as to their nature were made.

Steam-volatile acids. These were determined on the faecal extracts of the normal diet preceding, and on the extracts following, the ingestion of crystalline cholesterol. The extracts from the second and third days were combined. The results obtained are shown in Table 7. Expressed on a kg.

Table 7. Steam-volatile acids excreted on the normal diet and after the ingestion of crystalline cholesterol

Total volatile acids (g.)

\begin{tabular}{|c|c|c|}
\hline \multirow{2}{*}{$\begin{array}{c}\text { Normal } \\
\text { diet } \\
\text { (5 days) }\end{array}$} & \multicolumn{2}{|c|}{ Cholesterol diet } \\
\hline & $\begin{array}{c}\text { Day } \\
1\end{array}$ & $\begin{array}{c}\text { Days } \\
2 \text { and } 3\end{array}$ \\
\hline $\begin{array}{l}2 \cdot 63 \\
7 \cdot 4\end{array}$ & $\begin{array}{l}2 \cdot 15 \\
30 \cdot 3\end{array}$ & $\begin{array}{r}1.57 \\
11.0\end{array}$ \\
\hline $\begin{array}{l}18 \\
18 \\
36 \\
17 \\
11\end{array}$ & $\begin{array}{r}22 \\
20 \\
39 \\
11 \\
9\end{array}$ & $\begin{array}{l}17 \\
19 \\
42 \\
13 \\
10\end{array}$ \\
\hline
\end{tabular}

body wt./day basis there was an increase in the daily excretion of total volatile acids on the first day after the ingestion of crystalline cholesterol, but the amount decreased on the second and third days. The distribution of the fatty acids was of the same general pattern on the normal diet and after the ingestion of crystalline cholesterol.

Ether-extractable acids. Two methods were used to study these acids. In the crystalline cholesterol experiment the acids were treated initially with light petroleum and separated into soluble and 
insoluble fractions. The soluble fractions were separated by the Twitchell method (see Hilditch, 1949) into 'solid' and 'liquid' acids, which were then investigated. The light-petroleum-insoluble fraction is described below.

In the egg-cholesterol experiment the total acids were converted into the methyl esters and separated by chromatography on alumina. The largest fractions were those obtained from the pure benzene eluates. These fractions were semi-solids and soluble in light petroleum and had no demonstrable optical activity. Other fractions were obtained which were insoluble in light petroleum and are described below. Each fraction from the separate collections was saponified and the recovered acids were separated by the Twitchell method into 'solid' and 'liquid' acid fractions. The acid equivalents and iodine values of these were determined. The results of the separation and the analyses of the light-petroleum-soluble fractions are given in Table 8, where also the total weights of the insoluble fractions are given. portion of liquid acids on the first day after ingestion but on subsequent days the proportion of solid acids was greatly increased. No marked changes were observed after the ingestion of crystalline cholesterol.

Solid acids. Some further investigations of the 'solid' acids from the light-petroleum-soluble acid fraction from the normal diet were made. The acids were converted into methyl esters and fractionally distilled in vacuo. The following acids (expressed as a percentage of the total) were found: tetradecanoic 12, hexadecanoic (palmitic) 61, octadecanoic 7, $\mathrm{C}_{20}$ and higher acids 17, and oleic 4. Palmitic acid is thus the major component.

Reversed-phase chromatography (Howard \& Martin, 1950) was carried out on the solid acid fractions, with the results shown in Table 9. The separation of individual acids was not as clear-cut as could be wished, but there was a good separation at $\mathrm{C}_{16}$ and $\mathrm{C}_{18}$. The values are given (as a percentage of the total) therefore for $\mathrm{C}_{16}$ and lower acids, and for $\mathrm{C}_{\mathbf{1 8}}$ and higher acids. In the first experiment the

Table 8. Amounts and properties of fractionated ether-extractable acids in lipids from faeces of a man on normal and on high-cholesterol diets

For methods of fractionation see text.

\begin{tabular}{|c|c|c|c|c|c|c|c|c|c|}
\hline & & & & ht-petrc & eum-solu & ble fract & & & \\
\hline & & & & lid acids & & & quid aci & & \\
\hline Diet & Days & $\begin{array}{l}\text { Wt. } \\
\text { (g.) }\end{array}$ & $\begin{array}{l}\% \text { of } \\
\text { total } \\
\text { soluble } \\
\text { acids }\end{array}$ & Equiv. & $\begin{array}{c}\text { Iodine } \\
\text { val. }\end{array}$ & $\begin{array}{l}\% \text { of } \\
\text { total } \\
\text { soluble } \\
\text { acids }\end{array}$ & Equiv. & $\begin{array}{c}\text { Iodine } \\
\text { val. }\end{array}$ & $\begin{array}{l}\text { light-petroleum- } \\
\text { insoluble } \\
\text { fraction } \\
\text { (g.) }\end{array}$ \\
\hline $\begin{array}{l}\text { Normal } \\
\text { Crystalline cholesterol } \\
\text { Normal } \\
\text { Egg cholesterol }\end{array}$ & $\begin{array}{l}1-5 \\
1-3 \\
1-2 \frac{1}{2} \\
1 \\
2,3 \\
4\end{array}$ & $\begin{array}{l}9 \cdot 9 \\
4 \cdot 6 \\
2 \cdot 3 \\
1 \cdot 5 \\
4 \cdot 7 \\
3 \cdot 2\end{array}$ & $\begin{array}{l}58 \\
56 \\
48 \\
36 \\
71 \\
70\end{array}$ & $\begin{array}{l}290 \\
295 \\
266 \\
275 \\
257 \\
281\end{array}$ & $\begin{array}{r}13 \\
12 \\
8 \\
11 \\
7 \\
10\end{array}$ & $\begin{array}{l}42 \\
44 \\
52 \\
64 \\
29 \\
30\end{array}$ & $\begin{array}{l}383 \\
400 \\
285 \\
323 \\
311 \\
306\end{array}$ & $\begin{array}{l}40 \\
53 \\
84 \\
68 \\
89 \\
57\end{array}$ & $\begin{array}{l}3.3 \\
1.7 \\
1.6 \\
0.7 \\
1.5 \\
0.7\end{array}$ \\
\hline
\end{tabular}

Table 9. Reversed-phase chromatography of solid fatty acid fractions excreted on normal diets and after ingestion of crystalline cholesterol and of egg cholesterol

Values are given as percentage of total fraction.

$\begin{array}{cc}\begin{array}{c}\mathrm{C}_{16} \text { and } \\ \text { lower }\end{array} & \begin{array}{c}\mathrm{C}_{18} \text { and } \\ \text { higher } \\ \text { acids }\end{array} \\ \text { acids } \\ 60 & 40 \\ 60 & 40 \\ 55 & 45 \\ 65 & 35 \\ 62 & 38 \\ 59 & 41\end{array}$

There was a marked increase in the excretion of light-petroleum-soluble acids after the administration of eggs. There was some increase in the pro- acids excreted after the ingestion of crystalline cholesterol were pooled and there was no difference in the ratios obtained for them and those excreted on the normal diet. With the egg-diet experiment the ratio of $\mathrm{C}_{16}$ and lower acids increased after the ingestion of cholesterol, but the normal value was reached after 4 days.

Liquid acids. Apart from the values given in Table 8 no further investigations were made. In the first experiment the acid equivalents are much higher than, and the iodine values less than, those of oleic acid. With the egg-diet experiment the values for the excreted acids on the normal diet are similar to those for oleic acid, but after ingestion of eggs the acid equivalents were increased and in general the iodine values were decreased.

A spectrophotometric investigation gave a value of about $5 \%$ for linoleic and linolenic acids in the 
liquid acid fraction from the faecal extract on the normal diet. The value was not increased after cholesterol feeding.

It is presumed that the 'liquid' acids are a mixture of $\mathrm{C}_{18}$ and higher unsaturated acids, with oleic acid predominating.

Light-petroleum-insoluble acids. The acids excreted on the normal diet $(N, 3 \cdot 12 \mathrm{~g}$.) and all those excreted after the ingestion of crystalline cholesterol $(C, 1.53 \mathrm{~g}$.) were converted into methyl esters and treated with the Girard reagent. The ketonic fractions were dark tars $(N, 1.09 \mathrm{~g}$.; $C, 0.79 \mathrm{~g}$.). On treatment with ether a black insoluble portion was obtained which contained $2.5 \%$ of nitrogen. The ether-soluble fractions $(N, 0.84$ g.; $C, 0.46$ g.) were dark gums. Polarographic investigation gave waves characteristic of a 3-keto bile acid and a precipitate was obtained with an ethanolic solution of 2:4-dinitrophenylhydrazine. The materials were too dark for polarimetry. They contained about $1 \%$ of nitrogen.

The non-ketonic fractions $(N, 0.86 \mathrm{~g}$; $C, 0.45 \mathrm{~g}$.) were gums with no demonstrable optical activity. They were not further investigated.

On the egg diet, the light-petroleum-insoluble fractions were derived from the chromatography of the methyl esters of the acids from the normal feeding period, and from the first, the combined second and third, and the fourth days after ingestion. Fractions 2 were obtained from the $50 \%$ benzene $-50 \%$ ether eluents, fractions 3 from the pure ether eluents and fractions 4 from the $50 \%$ ether-50\% ethanol eluents. A final fraction was obtained from the extruded column with boiling ethanol containing $3 \%(v / v)$ of acetic acid.

The fractions 2 in all cases were light-green semi-solids which were slightly dextrorotatory. Fractions 3 were green tars and were dextrorotatory. Both fractions gave precipitates with ethanolic 2:4-dinitrophenylhydrazine. Fractions 4 were dark-green tars with a nitrogen content of $10 \%$.

The yields and appearances of the fractions from the normal diet and after the ingestion of eggs were similar; there was no increase after the intake of cholesterol.

The light-petroleum-insoluble fraction contains coloured nitrogen-containing acids derived from bile or from ingested chlorophyll, and keto acids which are possibly related to bile acids. The fraction is being studied further.

\section{Pigments}

All the neutral fractions were coloured to a greater or less degree, and coloured bands were present on the alumina columns. These were due to carotenoids present in the diet. The daily intake of carotenoids as i.u. of carotene per day was about
5000 , which is equivalent to about $30 \mathrm{mg}$. for 10 days. The carotenoids are known to be poorly absorbed (Hume \& Krebs, 1949). Spectrophotometric investigation of one fraction showed the presence of zeaxanthin and xanthophyll.

The acid fraction when converted into the methyl esters showed green bands, presumably of the chlorophylls, and brown-red bands, probably of the porphyrins. A brilliant red band was also seen. The coloured components appeared in the most polar fractions.

\section{DISCUSSION}

\section{Products of excretion}

After the ingestion of cholesterol there is an increased excretion of UM, which consists largely of sterols. The results given in Table 2 show that after the ingestion of crystalline cholesterol there is a greater excretion of UM which is mainly sterol. The amount of saturated sterol is greatly increased on the first day after cholesterol ingestion, and thereafter the amounts of saturated and unsaturated sterols are nearly equal. With the egg diet, on the first day after ingestion, the saturated sterols form a large part of the sterol fraction, but on later days the amounts of unsaturated sterols increase. The trend of values seems to indicate that on the first day after cholesterol ingestion there is an excretion of unchanged cholesterol and a marked intestinal conversion of cholesterol into coprostanol. The increased sterol excreted on subsequent days may represent re-excretion of absorbed cholesterol via the bile and subsequent intestinal conversion into coprostanol.

The difference between UM and total sterol precipitable by digitonin is due in part to compounds that are not steroids, such as hydrocarbons and aliphatic alcohols, but there is evidence that $3 \alpha$-stanols (fraction 4.1) are increased in amount. The limited information on the ketones shows that there is no great increase after cholesterol feeding. The small amount of 'fast-acting' sterols present in fraction 5.2 is slightly increased after sterol feeding, as are the most polar compounds, consisting in part at least of the diols.

The neutral fraction of the faecal extract of man, both before and after cholesterol ingestion, is similar to that of the rat except that the conversions of the cholesterol in man seem to be much slower (Cook et al. 1955).

The light-petroleum-soluble acids are a mixture of fatty acids and the light-petroleum-insoluble acids are a mixture, one part of which is possibly keto bile acids. From the results given in Table 8 it will be seen that there was an increased excretion of the total ether-soluble acids on the first day after the ingestion of crystalline cholesterol but on sub- 
sequent days the amount decreased. On the egg diet there was a continued increase in the excretion of total acids, which was paralleled by an increase in the solid acid fraction (mainly palmitic acid). There was a small rise in the excretion of esterified sterol as measured by the difference between free and total sterol, but this was not enough to account for the large increase in solid acids. It is tempting to relate the appearance of fatty acids to the disappearance of cholesterol, but such evidence is indirect. Unlike the findings with the rat, there was no coincidental increase in the excretion of the light-petroleum-insoluble fraction.

Unfortunately the steam-volatile acids were not determined in the egg-diet experiment, and only general conclusions can be drawn. An interesting feature is the amount of volatile acids present in the normal excretion. The main acids present are acetic and butyric acids. This confirms the earlier findings of Brieger (1877) and Cecchini (1923). Brieger noticed that a small amount of isobutyric acid was present in the volatile acid fraction. served by us. The values for the tritium-labelled cholesterol in the experiments of Biggs et al. (1952) were obtained for patients in a poor physical condition and, when calculated on an estimated kg. body wt. basis, show poor absorption. Their experiments and those of Favarger \& Metzger show clearly that the labelled cholesterol enters the blood stream. Ungar \& Dorfman (1953) have demonstrated absorption of ${ }^{14} \mathrm{C}$-labelled cholesterol into the blood stream, but only minute amounts were converted into steroid hormones. All workers on this subject are agreed that crystalline cholesterol is poorly absorbed and that the process of excretion is continued over a number of days. This result contrasts markedly with the ready absorption in experimental animals (see Cook \& Thomson, 1951).

Our results show that in the same subject egg cholesterol was more readily absorbed. The presence of the large amount of fat, and in particular lecithin, may be responsible for this effect. Eggyolk fat is readily digestible. Langworthy \&

Table 10. Reported values for the absorption of cholesterol in man, based on balance experiments

\begin{tabular}{|c|c|c|c|c|c|c|c|c|}
\hline \multirow[b]{2}{*}{$\begin{array}{c}\text { Form of } \\
\text { cholesterol eaten }\end{array}$} & \multirow[b]{2}{*}{$\begin{array}{l}\text { No. of } \\
\text { subjects }\end{array}$} & \multirow[b]{2}{*}{$\begin{array}{l}\text { Wt. } \\
\text { (kg.) }\end{array}$} & \multirow[b]{2}{*}{$\begin{array}{l}\text { Period } \\
\text { of } \\
\text { study } \\
\text { (days) }\end{array}$} & \multirow[b]{2}{*}{$\begin{array}{l}\text { Dietary } \\
\text { sterol } \\
\text { (g.) }\end{array}$} & \multirow[b]{2}{*}{$\begin{array}{l}\text { Sterol } \\
\text { excreted } \\
\text { (g.) }\end{array}$} & \multicolumn{2}{|c|}{ Sterol absorbed } & \multirow[b]{2}{*}{ Reference } \\
\hline & & & & & & $\underset{\text { (g.) }}{\text { Amount }}$ & $\begin{array}{c}\text { mg./kg. } \\
\text { body wt./ } \\
\text { day }\end{array}$ & \\
\hline $\begin{array}{l}\text { Crystalline sterol }(5.0 \mathrm{~g} .) \\
\text { in oil }(100 \mathrm{~g} .)\end{array}$ & 4 & - & 3 & $\begin{array}{l}\text { Range } 5 \cdot 8-6 \cdot 5 \\
\text { Mean } 6 \cdot 0\end{array}$ & $\begin{array}{c}1 \cdot 4-4 \cdot 2 \\
2 \cdot 7\end{array}$ & $\overline{\mathbf{3} \cdot \mathbf{3}}$ & - & $\begin{array}{c}\text { Bürger \& Winterseel } \\
(\mathbf{1 9 2 9 )}\end{array}$ \\
\hline $\begin{array}{l}\text { Crystalline sterol ( } 9 \cdot 8 \mathrm{~g} .) \\
\text { in oil (50 g.) }\end{array}$ & 1 & 71 & $\mathbf{3}$ & $11 \cdot 5$ & $9 \cdot 9$ & $1 \cdot 6$ & $7 \cdot 5$ & \multirow{2}{*}{ Present study } \\
\hline $\begin{array}{l}\text { Egg sterol (6.9 g.) and } \\
\text { fat ( } 357 \mathrm{~g} .)\end{array}$ & 1 & 71 & 4 & $9 \cdot 2$ & $4 \cdot 3$ & $4 \cdot 9$ & 17 & \\
\hline $\begin{array}{l}\text { Deuterium-labelled }(4.0 \mathrm{~g} .) \\
\text { in fat }(25 \mathrm{~g} .)\end{array}$ & ) & 75 & 3 & - & $1 \cdot 7$ & $2 \cdot 3$ & 10 & \multirow{2}{*}{$\begin{array}{l}\text { Favarger \& Metzger } \\
\text { (1952) }\end{array}$} \\
\hline $\begin{array}{l}\text { Deuterium-labelled }(3.0 \mathrm{~g} .) \\
\text { in fat }(60 \mathrm{~g} .)\end{array}$ & ) & 80 & 3 & 一 & $\begin{array}{r}0.7 \\
(\%)\end{array}$ & $\begin{array}{r}2 \cdot 3 \\
(\%)\end{array}$ & 9 & \\
\hline $\begin{array}{l}\text { Tritium-labelled (0.86 g.) } \\
\text { in fat ( } 85 \mathrm{~g} .)\end{array}$ & 1 & - & $\begin{array}{l}3 \\
\mathbf{7}\end{array}$ & - & $\begin{array}{l}66 \\
87\end{array}$ & $\begin{array}{l}34 \\
13\end{array}$ & - & \multirow{2}{*}{ Biggs et al. (1952) } \\
\hline $\begin{array}{l}\text { Tritium-labelled }(0.69 \mathrm{~g} .) \\
\text { in fat }(20 \mathrm{~g} .)\end{array}$ & 1 & 一 & $\begin{array}{l}\mathbf{3} \\
\mathbf{7}\end{array}$ & - & $\begin{array}{l}33 \\
57\end{array}$ & $\begin{array}{l}67 \\
43\end{array}$ & - & \\
\hline
\end{tabular}

\section{Absorption of cholesterol}

There are few reported experiments, using the balance method, on the absorption of cholesterol in man. In Table 10 are given values collected from the literature. When expressed on a kg. body wt./ day basis the values obtained by Favarger \& Metzger (1952) are similar to those obtained in this study. Bürger \& Winterseel (1929) do not give the weights of their subjects, but calculating on a $70 \mathrm{~kg}$. basis results of a similar order are obtained, although the percentage absorption found by these two groups of investigators were higher than ob-
Holmes (1917) found that feeding of egg-yolk fat equivalent to fourteen eggs per day for 3 days to six volunteers gave a digestibility coefficient for fat of $94 \%$, which compared with values of $97 \%$ for butter and $93 \%$ for beef fat. Long-continued consumption of eggs (as egg yolk) gives rise to increased levels of plasma cholesterol (Okey \& Stewart, 1933; Messinger, Porosowska \& Steele, 1950), and a massive dose taken over a short period causes a transient rise (Collen, De Kruif \& Geier, 1949). It is remarkable that under such favourable conditions there is not a much more marked absorption. 
The level of cholesterol in the plasma of man is the highest of all mammals, a fact which is difficult to explain. The reported half-life time of plasma cholesterol in man is 8-11 days (see Fukushima \& Rosenfeld, 1954), which indicates a turnover approaching that in experimental animals.

The picture given here is one of low absorption and of a slow metabolism as compared with the rat (Cook et al. 1955). Further experiments are needed to elucidate the fate of cholesterol in man.

\section{SUMMARY}

1. Cholesterol in the form of crystalline cholesterol (9.8 g.) and as egg cholesterol (6.9 g.) was taken by a human subject, and the course of intestinal excretion studied over 3 and 4 days respectively.

2. Analyses were made of the ether-ethanol extracts of the faeces for unsaponifiable matter, for free, total and saturated sterols and for steamvolatile and ether-extractable acids.

3. The crystalline cholesterol was absorbed to the extent of about $15 \%$ or about $8 \mathrm{mg} . / \mathrm{kg}$. body wt./day, and the egg sterol was about $60 \%$ absorbed or about $15 \mathrm{mg} . / \mathrm{kg}$. body wt./day. A transient elevation of the plasma level of cholesterol as esters occurred with the egg sterol.

4. The neutral fraction of the faecal extract was fractionated by chromatography and the main fractions were analysed.

5. The steam-volatile acids of the faecal extracts from the normal diet and after ingestion of crystalline cholesterol were analysed and shown to consist mainly of acetic and butyric acids.

6. The ether-extractable acids were fractionated by treatment with light petrolum. The soluble portion was separated into 'solid' and 'liquid' acid fractions which were analysed. The solid acid fractions were separated by reversed-phase chromatography.

7. The course of faecal excretion of lipid was followed, and a review is given of the balance method for studying cholesterol absorption in man.

Our thanks are due to the Medical Research Council for personal grants to D.C.E. and C.R. and a grant for expenses. Mr D. M. Robertson, Miss Elizabeth Wigg and Miss Margaret Mann helped with some of the determinations. Part of the expenses were borne by the Scottish Hospitals Endowments Research Trust.

\section{REFERENCES}

Biggs, M. W., Kritchevsky, D., Colman, D., Gofman, J. W., Jones, H. G., Lindgren, F. T., Hyde, G. \& Lyon, T. P. (1952). Circulation, 6, 359.

Brieger, L. (1877). Ber. dtsch. chem. Ges. 10, 1027.

Bürger, M. \& Winterseel, W. (1929). Hoppe-Seyl. Z. 181, 255.

Cecchini, A. (1923). Arch. Pat. clin. med. 2, 361.

Collen, M. F., De Kruif, D. \& Geier, F. (1949). Permanente Fdn. med. Bull. 7, 60.

Cook, R. P. (1952). Symp. biochem. Soc. no. 9, p. 14.

Cook, R. P. \& Edwards, D. C. (1951). Biochem. J. 49, xli.

Cook, R. P., Edwards, D. C. \& Riddell, C. (1952). Abstr. 2nd Int. Congr. Biochem. Paris, p. 123.

Cook, R. P., Edwards, D. C., Riddell, C. \& Thomson, R. 0. (1955). Biochem. J. 61, 676.

Cook, R. P. \& Thomson, R. O. (1951). Quart. J. exp. Physiol. 86, 61.

Edwards, D. C. \& Cook, R. P. (1951). Biochem. J. 49, xli. Edwards, D. C. \& Cook, R. P. (1955). Biochem. J. 61, 371.

Favarger, P. \& Metzger, E. F. (1952). Helv. chim. acta, 35, 1811.

Fieser, L. F. (1951). J. Amer, chem. Soc. 73, 5007.

Fukushima, D. K. \& Rosenfeld, R. S. (1954). In Chemical Pathways of Metabolism. Ed. by Greenberg, D. M. New York: Academic Press.

Gardner, J. A. (1921). Biochem. J. 15, 244.

Haslewood, G. A. D. (1941). Biochem. J. 35, 708.

Hilditch, T. P. (1949). The Chemical Constitution of Fats, 2nd ed. London: Chapman and Hall Ltd.

Howard, G. A. \& Martin, A. J. P. (1950). Biochem. J. 46, 532.

Hume, E. M. \& Krebs, H. A. (1949). Spec. Rep. Ser. med. Res. Coun., Lond., no. 264.

Klatskin, G. \& Molander, D. W. (1952). J. Lab. clin. Med. 39, 802.

Lange, W. (1950). J. Amer. Oil Chem. Soc. 27, 414.

Langworthy, C. F. \& Holmes, A. D. (1917). Bull. U.S. Dep. Agric. no. 507.

McCance, R. A. \& Widdowson, E. M. (1946). The Chemical Composition of Foods. 2nd ed. London: H.M. Stationery Office.

Messinger, W. J., Porosowska, T. \& Steele, J. M. (1950). Arch. intern. Med. 86, 189.

Okey, R. (1945). J. Amer. diet. Ass. 21, 341.

Okey, R. \& Stewart, D. (1933). J. biol. Chem. 99, 717.

Riddell, C. \& Cook, R. P. (1955). Biochem. J. 61, 657.

Robertson, D. M. (1955). Biochem. J. 61, 681.

Schoenheimer, R. \& Hilgetag, G. (1934). J. biol. Chem. 105, 73.

Ungar, F. \& Dorfman, R. I. (1953). J. biol. Chem. 205, 125.

Windaus, A. \& Uibrig, C. (1915). Ber. dtsch. chem. Ges. 48, 857. 